日臨外会誌 $48(6), 781-790,1987$

原著

電解式水素ガスクリアランス法による末梢血管病変の評価

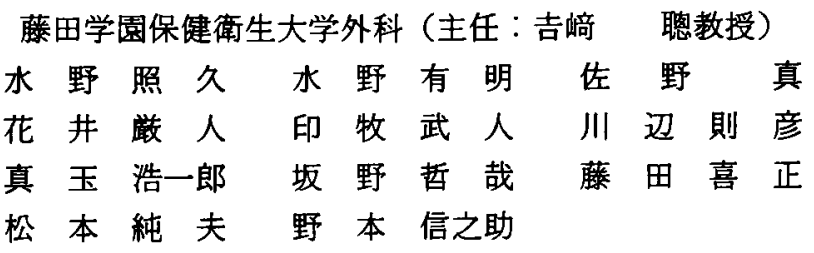

閉塞性動脈疾患の諸症状は末梢での組織血流量の低下による阻血によるものと考えら れ，その病態を把握するために画像診断法が行われるが, 上り重要な診断法として組織 血流量測定が必要となる。 そのひとつの検查法として比較的侵襲の少ない検査法である 電解式水素ガスクリアランス法を用いて，血行障害のある下肢を対象として腓腹筋の筋 組織血流量を血行再建術前後および安静時, 運動負荷時において測定した。 その結果, 閉塞部位別の組織血流量は中权より末梢での閉塞のほらが低值を示し, 同様に運動負荷 時の組織血流量の増加も末梢での閉塞の方が低值を示した. また血行再建術前後の比較 に括いても局所組織血流量測定は有用であった。ささらに糖尿病性血管症では動脈造影上 明らかな閉塞が認められなくても運動負荷の組織血流量の増加が少なく, 動脈硬化症と 異なった病態が考えられた。

卖引用語：電解式水素ガスクリフランス法, 筋組織血流量, 末梢血管障害, 無侵襲検查法

\section{I. 緒 言}

末梢血管疾患の診断に扣いて最も信頼されるものと しては血管造影があげられるが，数年前から無侵襲性 に診断しょらとする研究が盛んになった。その観点か ら画像診断の上では RI angiography ${ }^{122)} \mathrm{DSA}^{3 / 4)}$ が, また血流動態検查としてドップラー5) 7)を中心とした 検査法の発達がみられた。しかしいずれも大中血管の 病変の検査法であり, 最も重要な組織血流量を知る方 法は相変わらず少なく，わずかに経皮酸素分王測

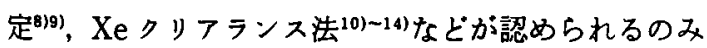
である，そこで我々は成るべく侵襲が少ない方法でか つ大きな器械も必要とせす簡便な組織血流量診断法々 して電解式水素ガスクリアランス法を用いているので その臨床応用成績について報告する.

\section{II. 目 的}

電解式水素ガスクリアランス法を用いて

（1）健常人の安静時血流量と運動負荷時組織血流量 を比較検討する。

（2）動脈閉塞部位別での組織血流量の差異を検討す
る.

（3）血行再建術前, 術後の組織血流量の変化, なら びに安静時, 運動負荷時による組織血流量の変化を検 討する.

$$
\text { III. 万法 }
$$

\section{1. 原理}

吸入式水素ガスクリアランス法の欠点を改良すべく 1974年 Stosseck ら ${ }^{15)}$ が考案したのが電気分解により 局所に水素ガスを発生させ局所血流量を求めようとし たのが電気分解式水素ガスクリアランス法である. 吸 入式の電極に微量の電流を流して電極間に電気分解を おこして水素ガスを発生させ，水素ガスが血流によっ て運び去られ，水素濃度の低下していく過程をボーラ 口電流検出により記録しクリアランスカーブより組織 血流量を求めるあのである(6)17).

\section{2. 計算方法}

Stosseck, 甲州ら ${ }^{18) 199} よ り$

血流量 : $F=\operatorname{In} 2\left(1 / T_{A}-1 / T_{B}\right)$

$$
=69.3\left(1 / \mathrm{T}_{\mathrm{A}}-1 / \mathrm{TB}_{\mathrm{B}}\right)
$$

$(\mathrm{ml} / \mathrm{min} / 100 \mathrm{~g})$ 
Тв: 心停止後の水素分圧

となるがクリフランスの半減時間を利用して

血流量：F=69.3/T1/2

$\mathrm{T}_{1 / 2}$ : 半減時間

から算出できる。しかし電解式水素ガスクリアランス には拡散によるみかけの血流量が存在するので，この 値を減ずることにより絶対值が得られると考光切断肢 をもちいてみかけの血流量をすとめた。

3. 使用器貝

ユニークメディカル社製 UHメーター（PHG-201. $\mathrm{H})$

Zニークメディカル社製ディシタルデータュニット (DDU-101)

日本科学社製平衡型記録計（U-228）

電極：関電極および不関電極

以上より構成される。

ディシタルデータユニットはクリアランスカーブの 半減時間から演算回路にて血流量を直接測定する機械 である.

\section{IV. 对象症例}

総数109例，333肢，636手技を対象とした（表 1 ）。

\section{V. 測定項目および結果}

(Mean $\pm \mathrm{SD} \mathrm{ml} / \mathrm{min} / 100 \mathrm{~g}$ )

A. 切断肢をもちいた見かけの血流量の測定：急性 動脈閉塞にて切断術を施行した切断下肢の腓腹筇の血 流量を測定し14.1の結果を得た。また同一部位での吸 入式水素ガスクリアランス法と電解式水素クリアラン ス法の測定值の差は13.8の值を得た。

B. 健常下肢の血流量：健康人10名20肢の安静時血 流量を測定した。ささらに運動負荷にて血流量がどのよ 5に变化するかを知るために 40 回の足関節の屈伸運動 を負荷した後に血流量も測定した．結果は（図 1) に 示した。

また運動負荷時/安静時筋血流比は $2.3 \pm 1.0$ となっ た.

C. 急性動脈閉塞：急性動脈閉塞にて入院してきた 患者 3 名につき術前術後の血流量を測定した，な抗こ の疾患にかぎっては疼痛のために患肢の運動負荷は不 可能であった，各症例の湘定値を（表 2）に示し，症 例 3 の部位別の測定値は（図 2）に示した。

D. 慢性峌脈閉塞：慢性動脈閉塞にはTAO ASO があり，また閉塞部位によっても腓腹筋血流量が 変化するのが予想されたため，以下のように閉塞部位 別に分類し，それぞれの血流量を測定した。
表 1 䌊对象症例数

\begin{tabular}{|c|c|c|c|}
\hline 総 数 & 109挒 & 333肢 & 636手技 \\
\hline 正常例 & 10例 & 20肢 & 40手技 \\
\hline ASO & 53例 & 221肢 & 400 手技 \\
\hline TAO & 14例 & 28肢 & 56手技 \\
\hline 急性動脈閉塞 & 3例 & 6肢 & 20手技 \\
\hline 棯尿症血管症 & 10例 & 20肢 & 40手技 \\
\hline 大動脈癌 & 4例 & 8肢 & 32手技 \\
\hline 勒静脈惟 & 3例 & 6肢 & 24手技 \\
\hline その地 & 12例 & 24肢 & 24手找 \\
\hline
\end{tabular}

$(n=20)$

$*: P<0.01$

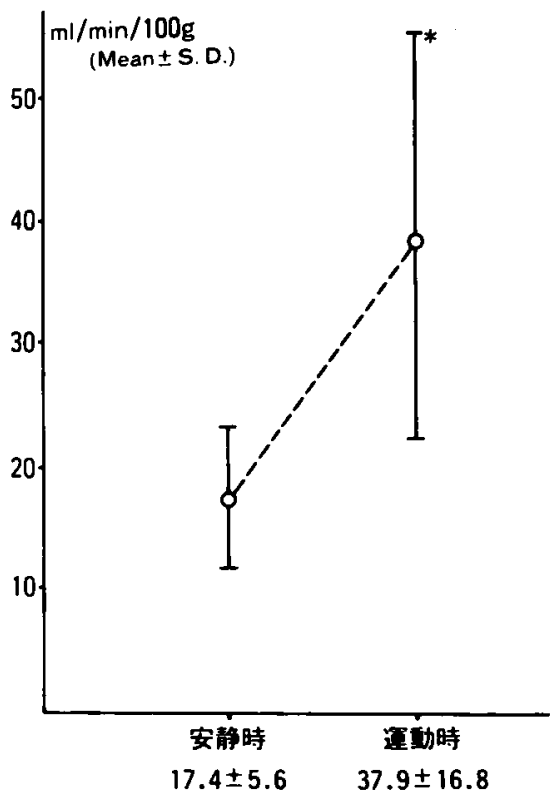

图 1 健常下肢安静時及U゙廷動時血流量

表 2 急性勤䛲閉害の筋血流

\begin{tabular}{|c|c|c|c|c|}
\hline & \multicolumn{2}{|c|}{ 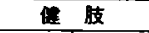 } & \multicolumn{2}{|c|}{ 急 肢 } \\
\hline & 尃前 & 行得 & 涉前 & 郝後 \\
\hline $\begin{array}{l}\text { 症例 } 1 \\
70 \text { 坡 }\end{array}$ & 22.2 & 9.0 & 14.2 & 28.2 \\
\hline $\begin{array}{l}\text { 症例 } 2 \\
65 \text { 荿古 }\end{array}$ & 28.2 & 10.1 & 3.2 & 26.2 \\
\hline $\begin{array}{l}\text { 症例 } 3 \\
68 \text { 地合 }\end{array}$ & 11.4 & 15.6 & 5.8 & 4.9 \\
\hline
\end{tabular}

\section{分類}

1） TAO（滕䈑動脈以下の閉塞）

2) $\mathrm{ASO}$

a. 膝窝動脈以下の閉塞

b. 大腿憷窝動脈以下の閉塞 


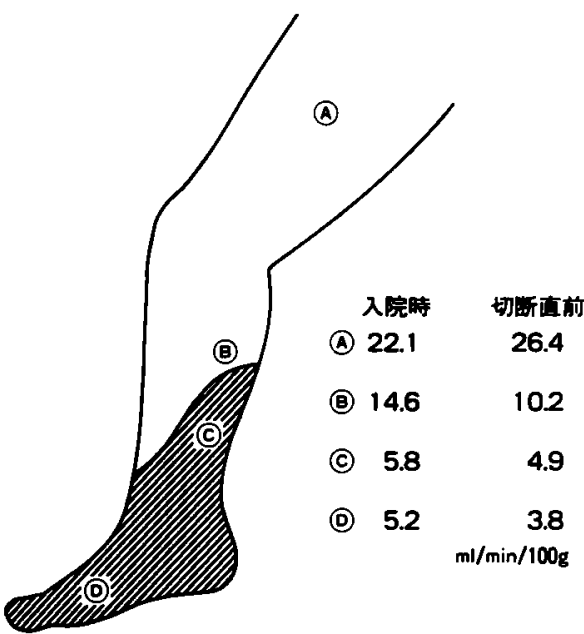

$Y$ 死 部

図 2 急性㔚脈閉塞（右下肢）の部位別筋血流

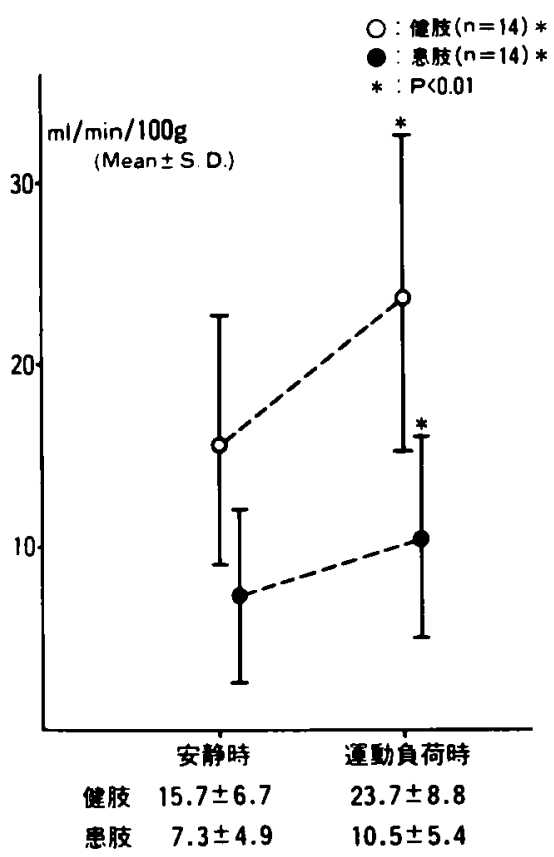

图 3 TAO 安静時, 更功色荷時筋血流量

c.一側性大動脈一腸骨動脈領域の閉塞

d. 両側性大動脈一腸骨動脈領域の閉塞 (Leriche 症 候群)

1) $\mathrm{TAO}$

この疾患群は14例ですべて男性であり，平均年㱓は 44.3葴で罹患肢は 9 ：5で右が多かった。すべての症 例は動脈造影にて閉塞部位の確認がされている。結果

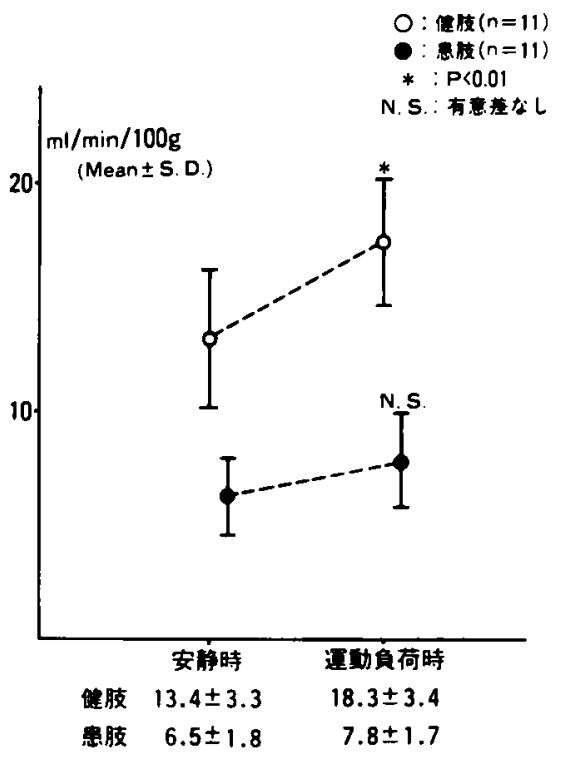

図 4 滕莴劸脈以下の閏塞：安静時運動負荷時筋血流 욜

は（図 3)に示した。また運動負荷時/安静時筋血流量 比は健肢 $1.9 \pm 1.5$ ，患肢 $1.4 \pm 0.8$ の結果となり，罹患 肢の組織血流量は正常群と比校して安静時, 運動負荷 時とる低い結果を得た。

2) ASO

a. 膝窝動脈以下の閉塞.

对象症例11例。平均年此 62.8 歳。男女比は 9:2. 罹患肢は右 6 例，左 3 例，両側 2 例であった。この群 は中枢側には閉塞はなく壁の不正程度の症例のみとし た，両側の膝窩動脈閉塞例は症状の強いは5を患肢と した。結果は（図4）に示した。また運動負荷時/安静 時筋血流量比は健肢において $1.4 \pm 0.3$, 患肢では1.3土 0.2 值を得た。この結果は運動負荷による血流量の増 加が覀いことが証明された。

b. 大眼一膝窩動脈閉塞

対象症例15例，平均年龄65.2歳.すべて男珄であっ た。左右差は1：2で左側に多かった。手術は腸骨動 脈にて血栓内膜摘除術を施行し大駺動脈以下の閉塞に 対しては何む行わなかった。それらの8 例には術後の 筋血流量も測定した。結果は（図 5，6）に示した.

c. 一側性大動脈一腸骨動脈領域の閉塞 症例数17例, 平均61.5歳すべて男性. 閉塞部位は右

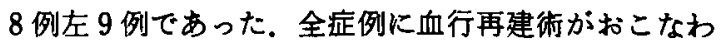
れた，血栓内膜摘除術が 9 例，腋窝動脈一大腿動脈 イハスが 6 例, 大駺一大駺ハイバスが 2 例施行された。 


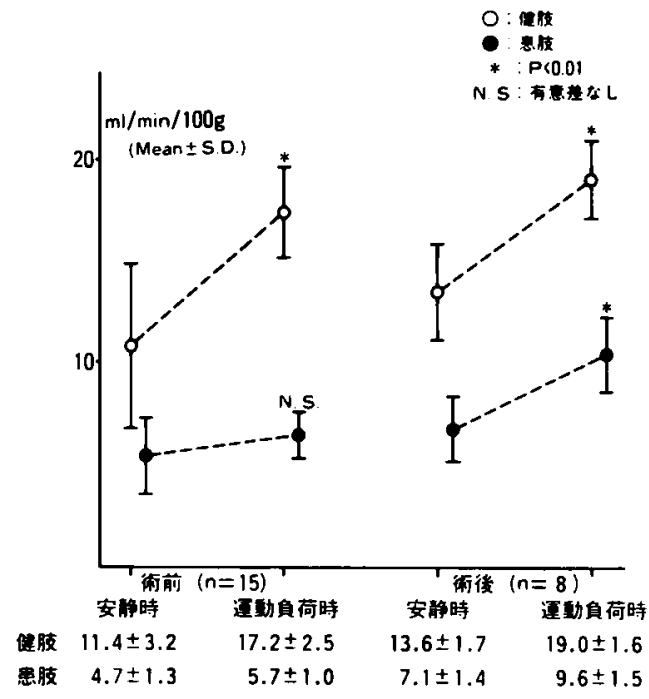

図 5 大腿膝富動脈閉塞：術前術後および安静時運動。 負荷時筋血流量

N. S.：有意差なし

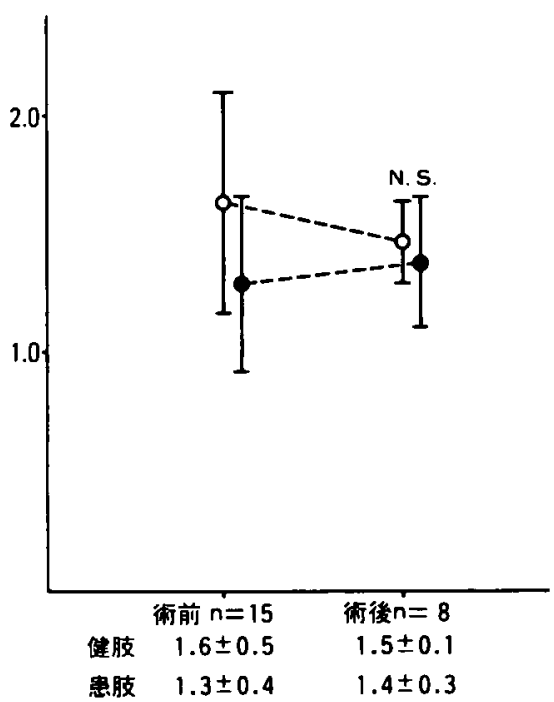

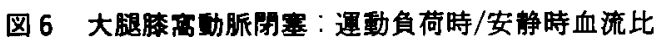
の術前術後の变化

結果は（図 7,8) に示した。

d. 両側性大動脈腸骨動脈領域の閉塞 (Leriche 症候 群)

症例数 10例 平均年龄63.5歳，すべて男性，すべて の症例に血行再建術が行われた。腋窝動脈一大腿動脈 ハイイバス 8 例，血栓内膜摘除術 1 例，Y型人工血管置

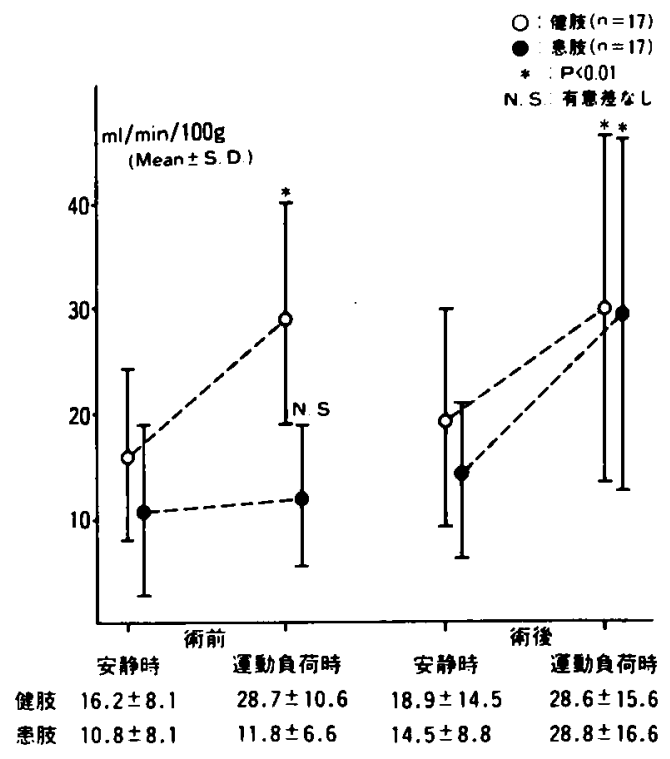

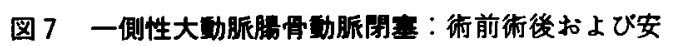
静時運動負荷時筋血流量

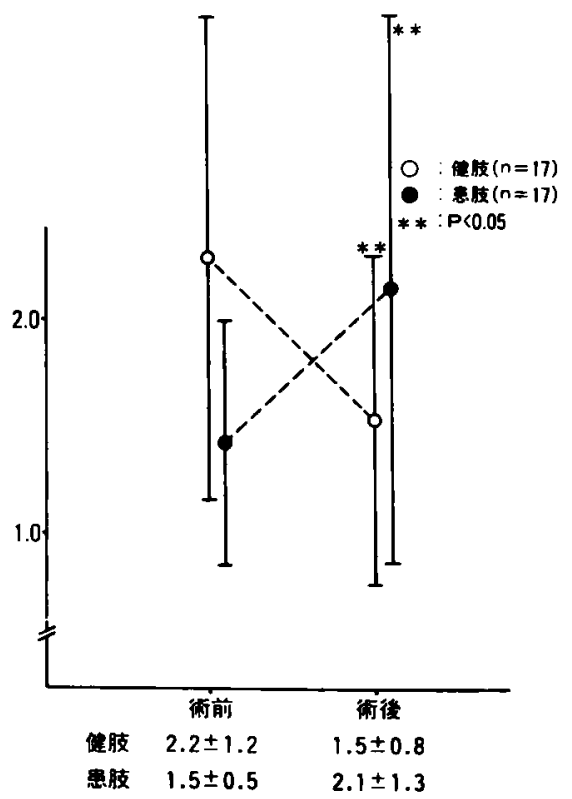

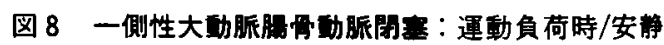
時血流量比の術前術後の比僌

換術 1 例であった。その5ち5例につき術後の下肢組 織血流量を測定した。結果は（図 9，10）に示した。

E. 精尿病性血管症

症例数10例, 平均年龄58.8歳, 男女比は $1 ： 1$ であっ た. ASO との合併は男性症例すべてにみられたが，動 


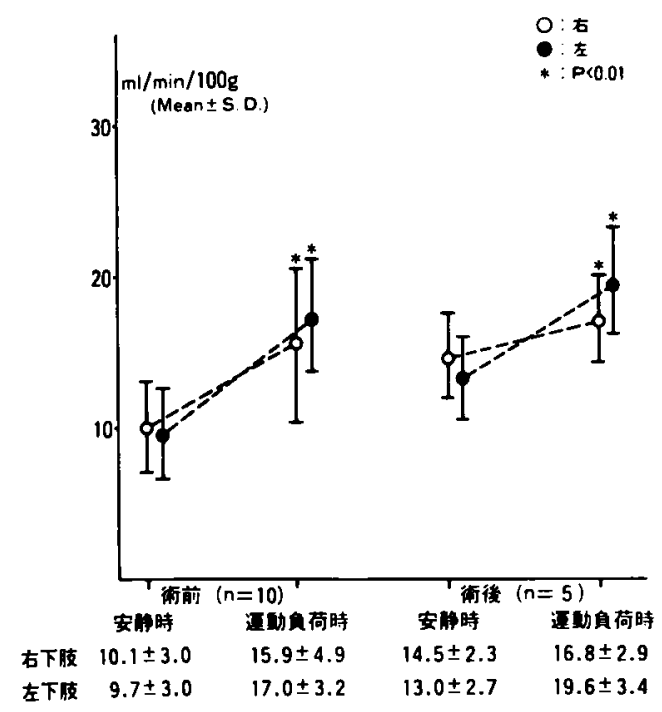

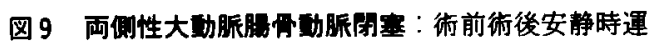
陲負荷時の筋血流早

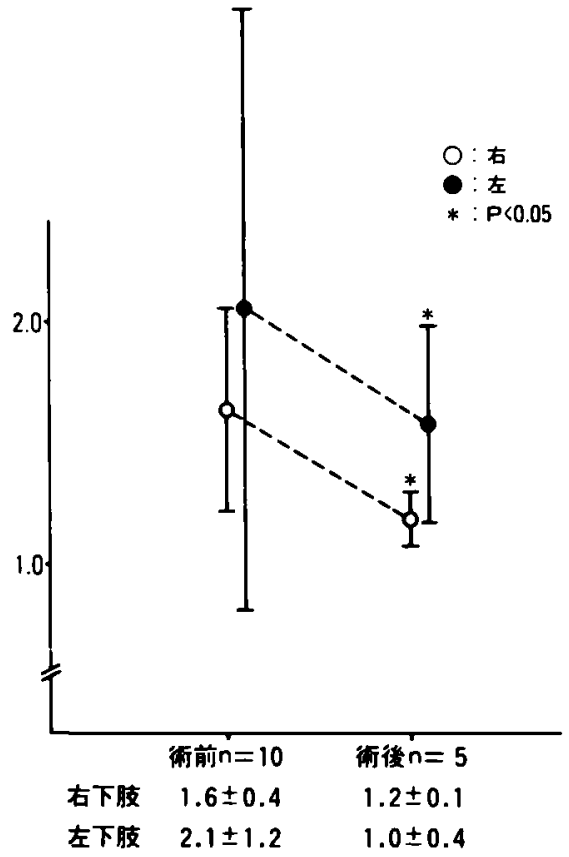

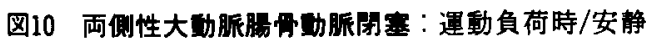
時血流早比の術前衍後の比較

脈造影上 ASO が軽度の症例であったためこの症例に 入れた。結果は（図11）に示した。 また運動負荷時/安 静時筋血流量比は健肢 $1.3 \pm 0.2$, 患肢 $1.1 \pm 0.4$ と低值 をとり，その值はASO 症候群と比較してもさらに低

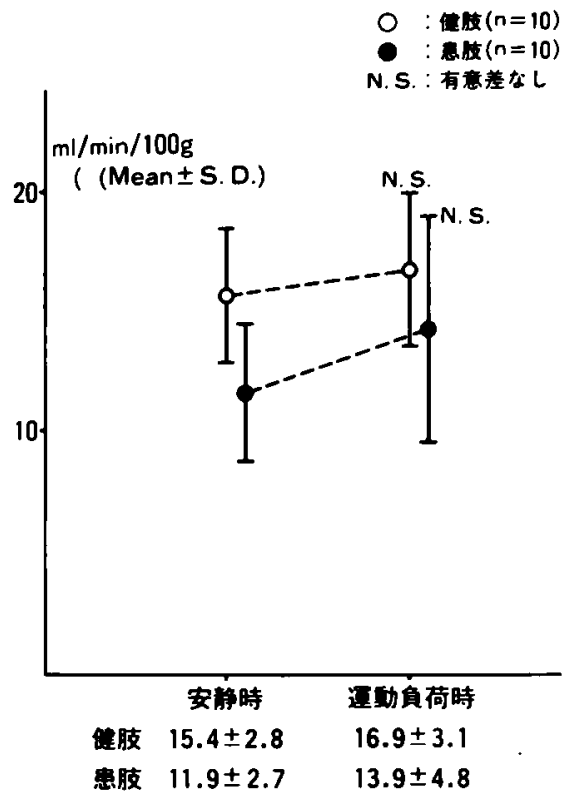

図11 楛尿病性血管症

表 3 Klippel-Weber 症候群における皮暔及び能血 流是

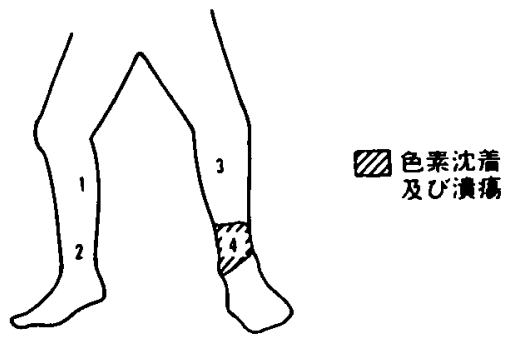

\begin{tabular}{|c|c|c|c|c|c|}
\hline & & 1 腓覆筋 & 2 皮的 & 了腓腹解 & 4 皮周 \\
\hline \multirow{2}{*}{$\begin{array}{c}\text { 症 } \\
\text { 例 } \\
1 \\
\end{array}$} & 安 鿇 時 & 17.8 & 38.9 & 18.9 & 20.8 \\
\hline & 逞娌角丽時 & 23.4 & 54.2 & 34.4 & 41.1 \\
\hline \multirow{2}{*}{$\begin{array}{l}\text { 症 } \\
2 \\
2\end{array}$} & 安 保 時 & 13.2 & 31.9 & 18.9 & 57.4 \\
\hline & 通動目荷時 & 26.3 & 54.2 & 54.8 & 85.8 \\
\hline \multirow{2}{*}{$\begin{array}{l}\text { 症 } \\
3 \\
3\end{array}$} & 安 觧 時 & 21.7 & 24.4 & 22.7 & 24.5 \\
\hline & 通動角荷時 & 25.9 & 28.2 & 26.6 & 33.4 \\
\hline
\end{tabular}

値であった。

\section{F. 動静脈瘄}

Klippel-Weber 症候群 3 例につき皮用の健常部，色 素沈着部抽よ゙腓腹筋の血流量を測定した。平均年龄 15歳，男 2 名女 1 名患肢はすべて左下肢であり結果は （表 3）に示した。この疾患群においては健常部と皮席 


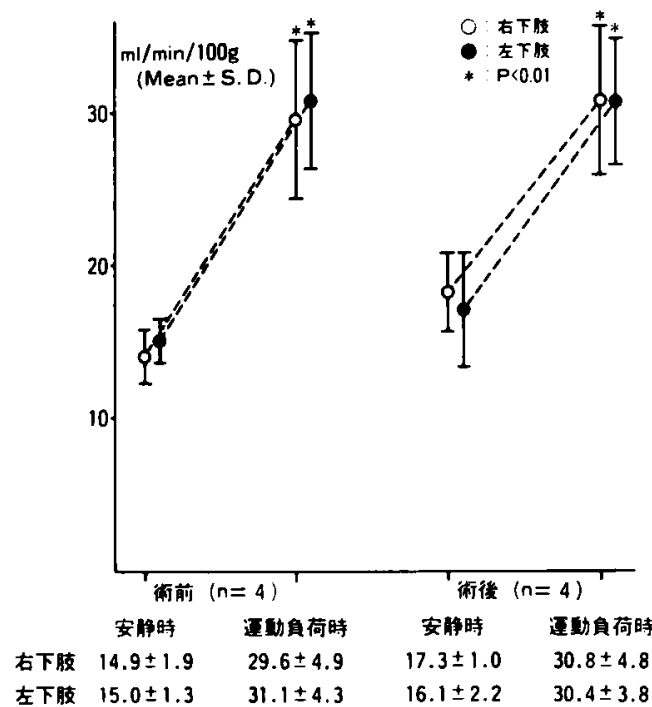

図12大功脈痛：術前術後㧍よび安静時運動負荷時筋 血流量

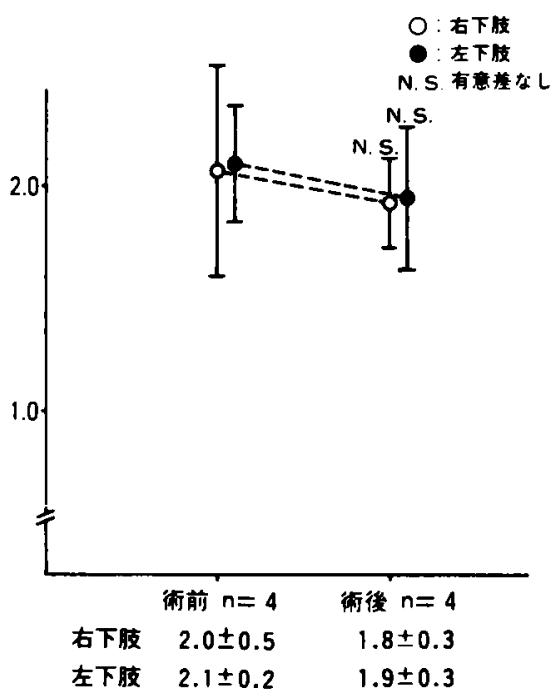

图13大勋脈舟：運動負荷時/安静時筋血流量比の術 前術後の変化

欠損部では有意差は特に認められなかった。

\section{G. 腹部大動脈瘦}

症例数 4 例 平均年齢66.8歳，すべて男性の症例で あった，全症例にY型人工血管置換術を施行した。

この症例群は対象患者がすくなかったが術前術後の 下肢組織血流量を測定した。結果は（图12，13）に示 した．予想されたように人工血管置換術によって下肢 血流量にはとくに影響は諗められなかった。
最後に対象症例すべての運動負荷時/安静時筋血流 量比を比較するために（図14）にまとめた.

\section{VI. 考按}

閉塞性動脈疾患に打いて画像診断法より血行動態を 知ることは重要であるが局所の組織血流量を把㩧する 事も必要と考之電解式水素ガスクリアランス法により 組織血流量を測定した，電解式水素ガスクリフランス 法はStosseck らによって実用化されたが，吸入式を 開発した Aukland ${ }^{20221)}$ 以前にも1945年 Kety ${ }^{22)} ら は$ 室 素ガスを吸入させ脳，心筋，堅の組織血流量を測定す る事を試みた結果を報告している．1956年 Misrahy ${ }^{231}$ は水素ガスクリフランス法による稱局所血流量の測定 を試み，1959年 Clark，Bargeron ${ }^{2425)}$ は血管内に留置 した電極により心疾患の左一右シャントを証明した。 1961年 Hyman ${ }^{26)}$ はポーラログラフをちいて電極に 印加電圧を加えることにより電位としてあらわす技術 を紹介したが，1964年になり Aukland は卧葴の血流量 を測定した，現在までに臓器または組織の血流量測定

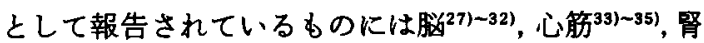

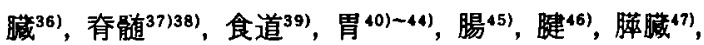
肝臓 ${ }^{48)}$ ，骨膜 ${ }^{49)}$ ，脈絡膜 ${ }^{50151)}$ などがある。

水素ガスは生体内においては不活性で，消費産生さ れないため生体内に水素ガスを供給しなければならな い，その供給方法には経静脈的に投与する方法と呂入 による方法があり，一般には操作の容易なことから， 吸入による投与法が用いられている。すななっ肺を通 して血液中にはいった水素は血流により各組織に運ば れる.水素ガスが組織で跑和状態になったのち，水素 ガスの供給を停止して水素がスが血流によって運び出 される状態を電気的に増幅して記録しクリアランス カーブより算出する方法である。

しかし吸入式水素ガスクリフランス法には以下のよ らな欠点がある521.

（1）水素ガスを使用するために引火の危険性もあり 安全性に問題がある。

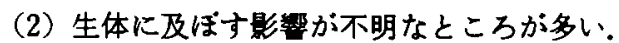

（3）虚血部位では水素ガスが飽和するのに時間がか かる，また飽和状態が把握できない。

（4）再現性に問題があり，連続的，経時的に椡定て きない。

特に（3）について動脈血の $\mathrm{PaO}_{2}, \mathrm{PaCO}_{2}$ 等を变化 させないためには一定の低濃度で吸入させる必要があ ク，虚血部位など本来血流量の低下していろ局所では 水素ガスを的和させるのに長時間が必要となり，組视 
で水素が飽和状態にあるのが把握するのが困難な場合 も考えられる.（4）についてる生体内から完全に水素 ガスが排出されていないと再度測定する場合正確な值 が得られないため，短時間に経時的な測定は不可能で ある，従って運動負荷を加える場合にも測定までの時 間がかかっていたのでは測定時には安静時と同じ条件 になるおそれがあり運動負荷時の血流量測定には適さ ない，以上の欠点を補うべく電解式水素ガスクリフラ ンス法を用いて組峨血流量を測定することを試みたと ころ良好な結果を得た。しかし吸入式水素ガスクリア ランス法と根本的に異なる点は電気分解によって発生 する水素ガスは極めて狭い範囲に限られる点に問題が ある. すなわち吸入式本素ガスクリフランスでは周囲 の水素浱度は同じであるが電解式水素ガスクリフラン ス法では，周囲に拡散していく水素ガスの量を無視で きないこの払散による電位の低下すクリフランスと して計算されてしまうために，実際の血流量よりも多 く算出される．つまり，実際の血流量は計算されたも のからみかけの血流量の值を差し引いたものといえ る.このみかけの血流量の測定法には 2 つの方法があ ク，ひとつはまったく血流のない状態で電気分解をお こして払散量を求める方法, 他のひとつは電解式水素 ガスクリフランス法で湘定された值から吸入式水素ガ スクリアランス法で測定された値を差す引く方法であ る.理論的にはどちらの値も同じ值を取るはずであり， そのために切断肢をすちいて測定したところ14.0とい ら数值を得た ${ }^{53)}$.ささらに切除した大胸筋でも測定し 14.8の值を得た。また吸入式と電解式による血流量の 盖を求めるために，下肢を用いて同一部位にて測定し たところ，13.8の値を得た。この値はまったく血流量 の無い状態でのみかけの血流量と近似していた。この 値は筋組織のみかけの值であり他の葴器では少なから す巽なってくるものと考える。したがってほかの臟器 の組織血流量を本法にて湘定する場合にはいずれかの 方法でみかけの血流量を知る必要がある。

また組織血流量の測定時に明らかに異常と思われる 高い血流量が出ることがあった。これは電極を血管の 中に刺入した場合と考えられ，刺入部位の変更が必要 であった54)55)。

またクリフランスカーブより組織血流量を算出する 場合に, 片対数グラフにプロットすることが必要たが， その際に検者によって若干の誤差が出ることがある. その誤差をなくし測定値の信頼性を高め，計算時間の 短樎をはかるためにディシタルメーターを用いた。
このディジタルメーターは有用であったが，被検者 の体動がクリアランスカーブに影羱することがあり， それをチェックするために記録計でのモニターす必要 であった。

検查対象は主として閉塞性の動脈疾患としたか，そ の結果閉塞部位による血流量の差異が把握でき,さら に運動負荷時/安静時筋血流量比が有意義であった。

閉塞性の動脈疾患の病態把握や血行再建術の効果判 定に ankle pressure index (以下 API と略す) がしば しば使われるが,この API と組織血流量との相関はみ られなかった。この理由は API が主幹動脈の血流状態 を示しているために組織血流量とは一致しないと考察 する．臨床面においても血行再建術が良好な成績であ りながら間歇性跛行が残ったりする症例むあることか らも血行再建の効果を評価する場合, 本法はより詳細 な情報を提供するすのと考える。

本法は侵㜔も少なく，特殊な薬郕も必要とせず，大 きな設備や装置ではないのでべッドサイドです測定可 能であり, 器具の構造も簡単で操作も容易であること から有用な測定法である。しかし，より精細に病態を 把握するためには他の画像診断法や血流測定法の併用 も必要と考える。

\section{VII. 結 語}

1. 電解式水素ガスクリアランス法を用いて正常例 20肢, 動脈血行障害のある198肢636手技にて下肢腓腹 筋の組織血流量を測定した。

2. 電解式水素ガスクリアランス法におい、て拡散に 上るみかけの血流量は筋組織では $14.0 \mathrm{ml} / \mathrm{min} / 100 \mathrm{~g}$ の值であった。

3. 正常者の下肢組織血流量は平均 $17.4 \pm 5.6$ $\mathrm{SDml} / \mathrm{min} / 100 \mathrm{~g}$ であり, 運動負荷時には約 2.3 倍に増 加することが認められた。

4. 末梢動脈の閉塞部位別安静時組織血流量は, 中权 より末梢での閉塞の方が低い值をとり,運動負荷時/安 静時筋血流量比も同様に末梢での閉塞の方がより低值 であった。

5. 血管造影上明らかな動脈閉塞が認められなくて も糖尿病性血管症の患者の運動負荷時/安静時筋血流 量比は正常者より低值を示していた。

6.この測定法は侵袃も少なく,大きな装置や特殊な 薬剤を使用せず，再現性もあることから信頼性の高い 検查法で他の画像診断および血流量測定法との併用に よって血行障害判定にも有用な検查法と考える. 


\section{文献}

1）大島統男，井島 宏：四肢動脈閉塞性疾患におけ る RI 動態検㚗. 第 1 回血管に関する無侵襲診断法 研究会抄録集，45-46，1982

2）友成正紀，古川欽一，高橋雅俊：RI フンギオテン

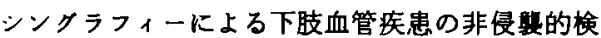
查法. 第 1 回血管に咸する無侵襲診断研究会抄録 果, 47-48, 1982

3）後藤平明，川口英敏，木本明博他：血管外科領域に おける Digital Subtraction Angiography の意義 について，第 3 回血管に関する無唚襲診断研究会 抄録集, 43-44, 1983

4）早川宏,山下裕也，三角幹夫他：Digital Angiography の血管再建術に対する有用性. 第 2 回血管 に関する無骎襲診断法研究会抄録集, 29-30, 1983

5）木村忠広，藤田喜正，川辺則彦他：Ultrasonic Doppler Angiographyによる末梢血管病変の診 断の検討，第 5 回血管に関する無侵嘒診断法研究 会抄録集，37-38，1985

6) 正木久男 : Doppler Sound Spectrum Analysis に 上る血行再建術の評価. 第3回血管に関する無侵㜔 診断法研究会抄録集, 3-4, 1983

7）木村忠広，水野照久，真玉浩一郎他：末梢血管病変 に対する Ultrasonic Doppler Angiography の評 価, 脈管学 $26: 21-28,1986$

8）応儀成二, 伊藤勝朗，川田知啓他：経皮的酵素分圧 測定による下肢血管障害の客観的評価，特にその 応用限界について．第 1 回血管に関する無侵襲診 断法研究会抄録集，35-36，1982

9）山本 尚, 藤原 蘶, 土光荘六他：組織酸素分圷上 りみた阻血肢の評価，第 5 回血管に関する無侵襲 診断法研究会抄録集, 11-12, 1985

10）下村忠朗：慢性下肢動脈閉塞症における ${ }^{139} \mathrm{Xe}$ 組 織クリフランス法による皮席・筋血流量に関する 研究一特に腰部交感神経切除術前後の変化につい $\tau$ 一, 脈管学 $17: 715-726,1977$

11) Lassen NA : Muscle blood flow in normal man and in patients with intermittent claudication evaluated by simultaneous $\mathrm{Xe}^{133}$ and $\mathrm{Na}^{24}$ clear. ance. J Clin Invest $43: 1805,1964$

12）井上幸愛，玉田得三郎，臼井孝他：Xe $\mathrm{Xe}^{133}$ による 胃血流量に関する研究，横浜医 $23: 317-322$, 1972

13) Bell G, Short DW : The measurement of blood flow through muscle from the clearance of radioactive Xe-non. Surg Gyencol obstet 127 :
61,1968

14）上田耕司：四肢動脈慢性閉塞性疾患における手衍 前後の血行動態— ${ }^{133} \mathrm{Xe}$ クリフランス法による研 究, 日外会誌 $84: 151-160,1983$

15) Stosseck K, Luebbers DW, Cottin N : Determination of local blood flow (microflow) by electrochemically generated hydrogen. Construction and application of themeasuring probe. Pfluigers Arch Eur J Physiol 348: 225 $-238,1974$

16) Hyman ES: Linear system for quantitating hydrogen at a platinum electrode. Circ Res 9 : 1093-1097, 1961

17) Hyman AL, Hyman ES, Quiroz A, et al : Hydrogen platinum elact rode system. Circulation $22: 766,1960$

18) Koushu K, Kamiyama K, Oka N, et al: Measurement of regional blood flow using hydrogen by eiectrolysis. Stroke $13: 483-487,1982$

19）甲州啓二, 遠藤俊郎，高久 晃他：電気分解により 発生させた办素ガスを利用しての局所脳血量测定 の試み, 脳神外科 $9: 1261-1266,1981$

20) Aukland K, Bower BF, Berliner RW : Measurement of local blood flow with hydrogen gas. Circ Res 14 : 164-187, 1964

21) Aukland $K$ : Hydrogen polarography in measurement of local blood flow, theoretical and empirical basis. Acta Neurol Scand 41 : 42-44, 1965

22) Kety SS, Schmidt CF : The determination of cerebral blood flow in man by the use of nitrous oxide in low concentrations. Am J Physiol 143: $53-66,1945$

23) Misrahy GA, Clark LC: Use of the platinum black cathode for local blood flow measure ments in vivo. Proc. Intl. Cong Physiol (Brussels) $20: 650,1956$

24) Clark LC Jr, Bargeron LM : Left to right shunt detection by and intravascular electrode with hydrogeng as and indicator. Science 130 : $709-710,1959$

25) Clark LC Jr, Bargeron LM: Detection and direct recording of right to left shunts with a hydrogen electrode catheter. Surgery 46: 797 -804, 1959

26) Hyman ES : Simple linear system to 
quantitate hydrogen at a platinum surface. Clin Res $9: 15,1961$

27) Symon L, Pasztor E, Dorsch NW, et al: Physiolosical respones of local areas of the cerebral circulation in experimental primates determined by themethod of hydrogen clearance. Stroke $4: 632-642,1973$

28) Doyle TF, martins AN, Kobrine AI: Estimating total cerebral blood flow from the initial slope of hydrogen washout curves. Stroke 6 : $632-642,1975$

29) Meyer JS, Fukuuchi $Y$, kanda $T$, et al: Retional cerebral blood flow measured by intra crotid injection of hydrogen. Neurology $22: 571$ $-584,1972$

30) Haining JL, Tumer MD, Pantall RM : Measurement of local cerebral blood flow in the unanesthetized rat using a hydrogen clearance method. Circ Res 23 : 313-324, 1968

31) Morawetz RB, DeGirolami U, Ojemann RG, et al : Cerebral blood flow determined by hydrogen clearance during middle cerebral artery occlusion in unanesthetized monkeys. Stroke 9 : 143-149, 1978

32) Heindenreich J, Erdmann W, Metzger $\mathrm{H}$, et al : Local hydrogen clerance and $\mathrm{Po}_{2}$ measurements in microareas of the rat brain. Experientia 26 : 257-259, 1969

33）丸山幸夫：心筋局所血流量に関する研究, 東北医 誌 $85 ： 217-215,1971$

34）木之下正彦, 高山幸男, 宮崎瑞夫他：水素クリアラ ンス法による心筋局所血流量の测定, 脈管学 $21: 183-188,1981$

35) Koyama $T$, Muratani $Y$ : A hydrogen catheter electrode for the determination of blood flow through organ tissue and coronary blood flow under continuous hypoxia. Jap J Physiol 21 : 209,1971

36) Neely WA, Turner MD, hardy JD, et al: The use of the hydrogen electrode to measure tissue blood flow. J Surg Res 5 : 363-369, 1965

37) Griffiths IR, Rowan JO, Crawford RA : Spinal cord blood flow measurement by a hydrogen clearance technique. J Neuro Sciences $26: 529$ $-544,1975$

38）田村 晃，浅野孝雄，佐野圭司：家鬼䈐蹎血流量の
測定一胸髄中心灰白質血流量と炭酸ガス反応性 一, 腅神経 $30: 383-386,1978$

39）宮本二郎，高瀬靖広，福富久之他：食道静脈瘤患者 における血行動態に関する内視鏡的検討, Gastroenterological Endoscopy 23 : 497-502, 1981

40）宮本二郎, 高瀬靖広, 竹島 徹他：内視鏡を応用し た胃粘膜下組織血流量の測定, Progress of Digestive Endoscopy 14:57-61, 1979

41）宮本二郎, 高瀬靖広, 竹島 徹他：内視鏡を応用し た胃粘膜下組織血流量の測定一，動物による基礎 的検討一, Gastroenterological Endoscopy 22 : $353-364,1980$

42）宮本二郎，高瀬靖広，竹島 琉他：胃漬瘍患者にお ける胃血行動態. Gastroenterological Endoscopy 23 : 497-502, 1981

43）宮本二郎：胃癌患者における胃血行動態，Gastroenterological Endoscopy $24: 193-203,1982$

44）西䏦英樹, 曾和融生, 梅山 㢣: 電解式組織血流計 を用いた胃粘膜血流の測定，日消誌 $80 ： 1656$, 1983

45) Mishima $Y$, Shigematsu $H$, horie $Y$, et al : Measurement of local blood flow of the intestine by hydrogen clerance method. Experimental study. Japan J Surg 9:63-73, 1979

46) Manske PR, Whiteside LA, lesker PA : Nutrient pathways to flexor tendons using hydrogen washout technique. J hand Surg $3: 32-36,1978$

47) Aune S, Semb LS: The effect of secretin and pancreozymin on pancreatic blood flow in the conscious and anesthetized dog. Acta Physiol Scand $76: 460-414,1969$

48）柿本隆生：水素クリフランス法による肝局所血流 量の研究, 日消誌 $79: 2267-2276,1982$

49）島晸, 山内茂樹, 松本忠美他：Free Vascularized Bone Graft $の$ 血流測定法，整形外科 35 ： $355-361,1984$

50）三好輝行, 松尾信彦, 小山鉄郎他：脈絡膜诺小壊 に及ほすす血管払張剂の作用, Therapeutic Research 3: 578-582, 1985

51）松尾信彦，長谷川栄一，岡部史郎他：脈絡膜の特異 珄, 日眼会誌 $84: 2147-2206,1980$

52）坂野哲哉，丹 光明，木村忠広他：電解式組織血流 計による末梢血行動態の研究 (第 3 報)．第 3 回血 管に成する無侵襲診断法研究会抄録集，25-26， 1983

53）坂野哉, 竹内 正, 高山勝行他：水素ガスクリフ 
ランス式組織血流計による末梢血行動態の研究。

第 4 回血管に関する無侵競診断法研究会抄録集, $63-64,1984$

54）吉崎 聘, 竹内 正, 沓名哲治他：水素ガスクリア ランス式組䋘血流計による末梢血行動態の研究.

第 1 回血管比開寸る無唚俥診断法研究会抄録集,
$39-40,1982$

55）奴野暂哉，水野有朋，水野照久他：水素ガスクリフ ランス式組織血流計に上る末梢血行動態の研究。 第 2 回血管に関寸る無侵軗診断法研究会抄绿集, 49-50, 1983

\title{
EVALUATION OF PERIPHERAL VASCULAR DISEASE BY ELECTROCHEMICAL HYDROGEN CLEARANCE METHOD
}

\author{
Teruhisa MIZUNO, Yuuhou MIZUNO, Makoto SANO, Gento HANAI, \\ Taketo KANEMAKI, Norihiko KAWABE, Kouichiro MATAMA, \\ Tetsuya BANNO, Yoshimasa FUITTA, Sumio MATSUMOTO \\ and Shinnosuke NOMOTO \\ Department of Surgery, Fujita Gakuen Health University School of Medicine, Nagoya \\ (Director: Prof. Satoshi YOSHIZAKI)
}

Various symptoms in obstructive arterial disease seem to be derived from ischemia due to a decreased blood flow in the peripheral tissues. Diagnostic imaging is usually used to determine the pathological condition of the disease.

Determination of tissue blood flow, however, is a more accurate diagnostic method. By using the electrochemical hydrogen clearance method, which is less invasive, tissue blood flow was determined at the ischemic gastrocnemius muscle during rest and exercise, before and after revascularization. With regard to the site of obstruction, tissue blood flow was found to be lower in the peripheral region than in the central. The degree of increase in tissue blood flow during exercise was also lower in cases of obstruction in the peripheral region. Comparison of blood flow before and after revascularization demonstrated the usefulness of determining local tissue blood flow. In addition in cases of diabetic angiopathy, the degree of increase in tissue blood flow during exercise was low, even though there was no obvious obstruction on arteriography, suggesting a pathological nature different from that of arteriosclerosis. 